\title{
Reliability of a Centroid method to estimate head position in cephalometric diagnosis
}

\section{Confiabilidade de um método baseado no ponto Centróide para estimar a posição da cabeça no diagnóstico cefalométrico}

\author{
Hideo SUZUKI' ${ }^{1 D}$ https://orcid.org/0000-0002-7045-7095 \\ Selly Sayuri SUZUKI ${ }^{1}$ iD https://orcid.org/0000-0001-7493-746X \\ Aguinaldo Silva GARCEZ1 iD https://orcid.org/0000-0003-2037-7211 \\ Juliana Mandello CARVALHAES ${ }^{2}$ iD https://orcid.org/0000-0003-1472-204X \\ Denise Nami FUJII ${ }^{1}$ iD https://orcid.org/0000-0002-6896-7539 \\ Ynara Bosco LIMA-ARSATI ${ }^{3}$ iD https://orcid.org/0000-0002-1059-2797
}

\section{ABSTRACT}

Objective: The objective of this study was to 1) evaluate the reproducibility of natural head position (NHP) in different professional groups; 2) compare three cephalometric methods of estimating head position to the established natural head position and 3) investigate the applicability of a new method to estimated head position using a Centroid method. Methods: The sample consisted of 105 individual cephalometric tracings and photographs. For the first evaluation, copies of the lateral photographs were reproduced for each patient and 3 professionals with different expertise (experienced orthodontists, orthodontic students and orthognatic surgeon) were instructed to position the photographs in NHP. Later, 3 different methods to obtain NHP were assessed: 1) the Frankfort Horizontal Plane (FRANK), 2) Sella-Nasion $7^{\circ}$ Line (SN7) and 3) proposed Horizontal Reference Line based on Centroid. Angles formed by the evaluated planes/lines and True Vertical Line obtained were measured. Gender and skeletal discrepancy were considered. Results: The results showed a significant difference between NHP obtained from orthodontists and surgeons compared to students ( $p<0.0001)$. Also results showed no effect of skeletal classification and gender did on measurement ( $p>0.05$ ). Both SN minus $7^{\circ}$ and FRANK methods showed a high variability $(p<0,01)$ compared to Centroid method. Conclusion: NHP may be affected by the professional experience. The proposed horizontal line based on Centroid is a valid method for estimating head position, thus, may be indicated to use as a diagnostic tool in Orthodontics and Orthognatic Surgery.

Indexing terms: Orthodontics. Diagnosis. Orthognatic surgery.

\section{RESUMO}

Objetivo: Os objetivos deste estudo foram 1) avaliar a reprodutibilidade da posição natural da cabeça (PNC) em diferentes grupos de profissionais; 2) comparar três métodos cefalométricos para estimar a posição da cabeça e compará-los à posição natural

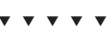

1 Faculdade São Leopoldo Mandic, Instituto de Pesquisa São Leopoldo Mandic, Ortodontia. Rua José Rocha Junqueira, 13, Swift, 13045-755, Campinas, SP, Brasil. Correspondence to: AS Garcez. E-mail: <garcez.segundo@gmail.com>.

2 Faculdade UniFTC Itabuna. Itabuna, BA, Brasil.

3 Universidade Estadual de Feira de Santana, Faculdade de Odontologia. Feira de Santana, BA, Brasil.

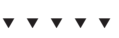

Suzuki H, Suzuki SS, Silva GA, Carvalhaes JM, Fujii DN, Lima-Arsati YB. Reliability of a Centroid method to estimate head position in cephalometric diagnosis. RGO, Rev Gaúch Odontol. 2020;68: e20200045. http://dx.doi.org/10.1590/1981-863720200004520190017 
estabelecida da cabeça e 3) investigar a aplicabilidade de um novo método para estimar a posição da cabeça usando o método Centróide. Métodos: A amostra foi composta por 105 traçados cefalométricos e fotografias individuais. Para a primeira avaliação, cópias das fotografias laterais foram reproduzidas para cada paciente e três profissionais com diferentes conhecimentos (ortodontistas experientes, estudantes de ortodontia e cirurgião ortognático) foram instruídos a posicionar as fotografias no PNC. Posteriormente, foram avaliados três métodos diferentes para obter posição estimada da cabeça: 1) o Plano Horizontal de Frankfort (FRANK), 2) a Linha Sella-Nasion $7^{\circ}$ (SN7) e 3) a Linha de Referência Horizontal proposta, baseada em Centróide. Os ângulos formados pelos planos/ linhas avaliados e pela linha vertical verdadeira obtidos foram medidos. Foram considerados a discrepância esquelética e o gênero. Resultados: Os resultados mostraram uma diferença significativa entre o PNC obtido por ortodontistas e cirurgiões em relação aos estudantes $(p<0,0001)$. Os métodos SN7 e FRANK apresentaram alta variabilidade $(p<0,01)$, enquanto o método baseado em Centróide mostrou menor variabilidade. Conclusão: a PNC pode ser afetada pela experiência profissional. A linha horizontal proposta baseada em Centróide é um método válido para estimar a posição da cabeça, portanto, pode ser indicada para uso como ferramenta de diagnóstico em Ortodontia e Cirurgia Ortognática.

Termos de indexação: Diagnostico. Ortodontia. Cirurgia ortognática.

\section{INTRODUCTION}

Cephalometric analyses have become indispensable in clinical Orthodontics and orthognatic surgery in order to obtain a proper diagnosis, treatment planning, therapy monitoring and evaluation of treatment results, as well as, craniofacial growth follow-up [1].

In order to determine skeletal maxillomandibular relationship by cephalometric analysis, two methods are most commonly used to guide head position, either using intracranial or extracranial references [2,3]. Intracranial reference, such as the Sella-Nasion line [1] and Frankfort horizontal [4] are widely used. However, landmarks used to determine these intracranial references may not be stable and may change continuously during growth, leading to greater variability among individuals. Therefore, these lines/planes are inherently unreliable and likely to mislead orthodontic diagnosis and treatment planning [3]. A recent study has shown that skeletal cephalometrics may lead to a different diagnosis of patient's facial characteristics [5].

Natural head position (NHP) is considered the most appropriate reference for skeletal discrepancies diagnosis and treatment planning and is the method of choice by many clinicians since is relatively easy to obtain $[2,3,5,6]$. NHP is a standardized and reproducible position, with patient in an upright head posture and eyes focused on a point at some distance and at eye level, in a horizontal vision axis $[5,6]$. A number of studies evaluating NHP registered in photographs and lateral radiographs recommend it as a reasonably stable position that could be used as a reference [7-9]. NHP obtained during x-ray acquisition seems more difficult that taken by photograph, probably due to the ear rods and the nasal support from the cephalostat which might disturb the natural position of the head [9]. In a recent review, Cassi et al. cited that assessment of craniofacial morphology is influenced by the experience and perceptions of the examiner, so the standard positioning of the patient is crucial for objective assessment, especially with use of Cone Beam Computed Tomography (CBCT) and 3D photographs [10].

Variability of less than $5^{\circ}$ may be considered acceptable and a variation between $2^{\circ}$ and $3^{\circ}$ can be found in most studies $[6,7,11,12]$. Madsen et al. [13] found that approximately $68 \%$ of individuals will reproduce NHP within a variation of $\pm 3^{\circ}$ and $95 \%$ of individuals within $\pm 6^{\circ}$ of difference from zero which means that for $2 / 3$ of the subjects. Thus, NHP reproducibility ranged within $\pm 3^{\circ}$, but $1 / 3$ ranged within $\pm 6^{\circ}$ which is clinically meaningful and could alter diagnosis and treatment plan ${ }^{11}$. In order to have more understanding of this issue, in figure $1 \mathrm{~A}$, we can observe a lateral facial photograph that has been modified in clockwise and counter-clockwise rotation every $1^{\circ}$ from the original head position to illustrate the clinical significance of this variability during NHP acquisition. In Figure $B$ and $C$, it is possible to better visualize how much $\mathrm{a} \pm 3^{\circ}$ and $\pm 6^{\circ}$ variation in NHP can be misinterpreted in daily clinical practice.

Centroid is a mathematical point that describes the geometric center of a polygon or also described in physics as the center of gravity of an object's shape. It has been introduced fifty years ago and its use in cephalometric research has been reported by a few investigators [14-18]. The explanation of why use Centroid in cephalometric research lies in that, Centroid represents the least variable, therefore, the most stable point of any area or volume, and it is not affected by increasing in size and/or changing in shape [17].

The purpose of this study was: 1) to evaluate the reproducibility of natural head position between three 


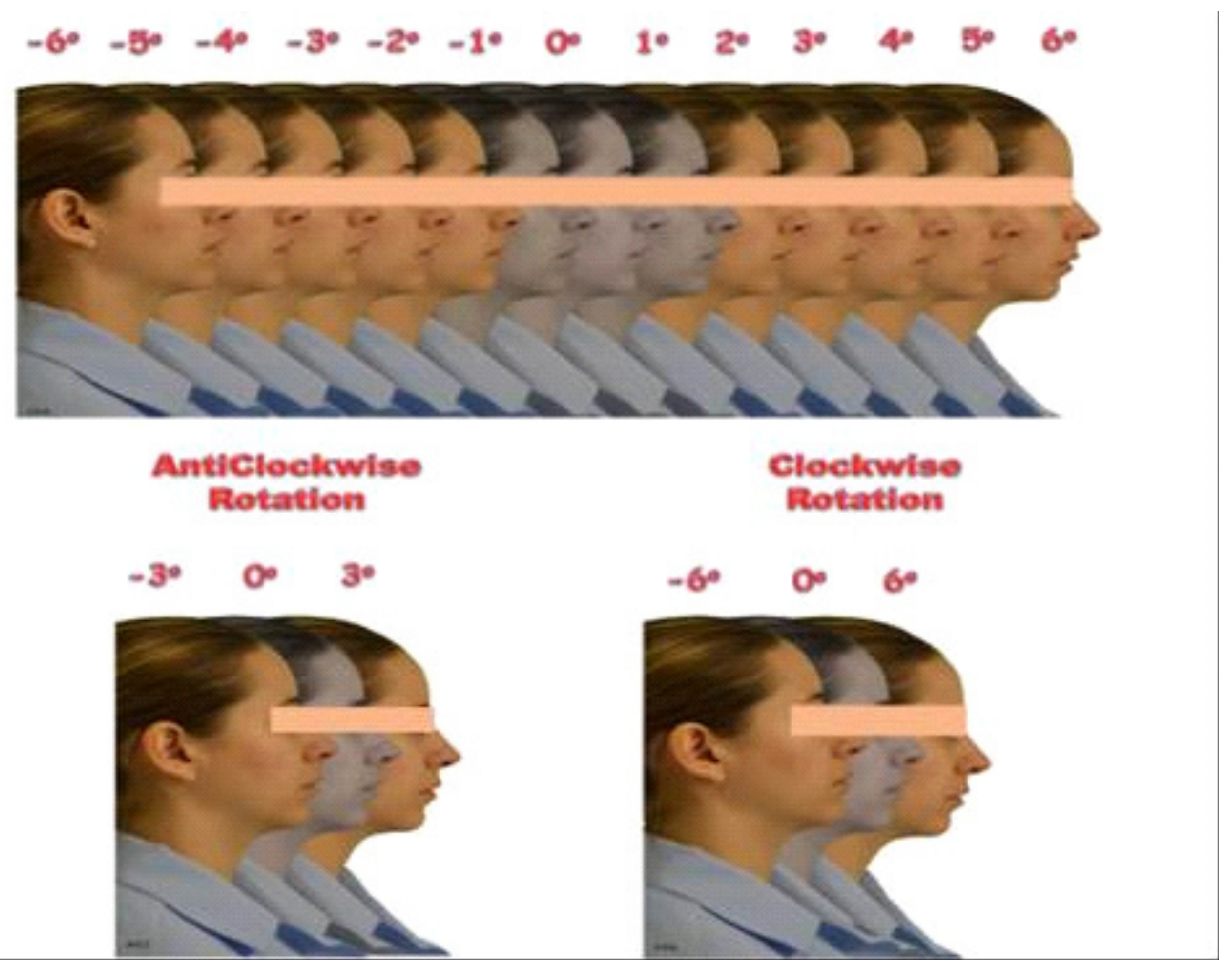

Figure 1. A- Profile pictures showing one degree rotation in clockwise and anticlockwise direction. B- Three degree rotation. C-Six degree rotation.

groups of clinicians with different professional experience; 2) to assess two methods of estimating head position using intracranial references and comparing them to the established natural head position and 3) to investigate the reliability and applicability of an estimated head position using a Centroid reference method.

\section{METHODS}

\section{Sample}

This prospective study was conducted after the approval of the St. Leopoldo Mandic Dental Research Center Ethical Committee of Human Studies \# 07/115.

The sample consisted of lateral photographs and cephalometric radiographs of 212 subjects, age varying from 12 to 48 years old divided in 4 groups: Group 1 consisted in 60 skeletal Class I patients (mean age 22.3 years old), Group 2 in 79 skeletal Class II and III patients (mean age 22.1 years old) and Group 3 in 73 patients presenting vertical discrepancies (mean age 18.5 years old). Inclusion criteria included: no orthodontic/orthopedic treatment, complete permanent dentition, no congenitally missing, extracted teeth or extensive restorations or prosthesis and no physically handicapped or visually impaired individuals.

Study 1 - For the lateral photograph, each patient was instructed to keep teeth gently in occlusion and to look at a mirror at eye level located at a $2 \mathrm{~m}$ distance. Patient was instructed to remain in a natural and relaxed body position. In the photograph, soft tissue of the patient facial profile was fully observed.

In order to evaluate and establish the correct natural head position obtained in the photographs, from the overall sample, 100 patients were selected and seven copies of the photograhs, seven copies of the photograph were reproduced for each patient, resulting in a total of 700 photographs that were cropped in a round shape, in order to avoid the effect of the paper margins during head positioning. After sample preparation, each set of 100 photographs were submitted for evaluation by: Group A) three orthodontists with more than 15 year of clinical experience; Group B) three students enrolled in the orthodontic program for 2 years and Group C) one experienced orthognatic surgeon.

All professionals were instructed to place the photographs in natural head position based on his/her own criteria and fixed it. After proper attachment of the photographs, Ricketts' E-line (a line drawn from nose tip 
to chin) was traced on the photograph and the angle between the E-line and a vertical line $(\mathrm{VL})$ parallel to the paper margin was measured (figure 2A).

Study 2 - Lateral radiographs were taken, and tracings were performed including soft and hard tissue drawings. Lines and planes used in this study included: SellaNasion line (SN); Sella-Constructed Gonion line (S-Goc); Nasion-Constructed Gnation Line (N-Gnc), mandibular plane (MP), Frankfort horizontal, and horizontal line $(\mathrm{HL})$, perpendicular to the vertical line.

For the Centroid method, a polygon geometric figure was traced using: anterior cranial base SN line representing the ceiling of the face, S-Goc representing the posterior limit of the face, N-Gnc representing the anterior limit of the face and MP as the floor (lower bound) of the face. In order to obtain a regular geometric form, middle points of each line were found and by tracing the transversal and vertical lines that connects the middle points, the Centroid point was found. A line was then constructed passing through the Centroid point and the Subnasal and extending it until it reached the $\mathrm{VL}$, this line was called Centroid Reference Line (CRL) (figure 2F). Additionally, two conventional methods, traditionally used, based on intracranial references were traced: SN7 ${ }^{\circ}$ and Frankfort horizontal.

All three methods were evaluated considering NHP as the gold standard method. Mean values of the angles obtained from NHP achieved by the four experienced professionals (orthodontists and the surgeon) in the first study of this study were used as reference to transfer the VL obtained in the photograph to the cephalometric tracing by using E-line as the common line to both photograph and tracing (figure 2B-C).

After transferring the $\mathrm{VL}$ to the tracing, a $\mathrm{HL}$ was drawn perpendicular to $\mathrm{VL}$, passing through the Sella, Porion and Centroid points in order to measure the angles for SN7 ${ }^{\circ}$, Frankfort horizontal and CRL, respectively (Figure 2D-F). When the $\mathrm{HL}$ was above CRL, FRANK or $S N 7^{\circ}$, values were considered negative and positive when $\mathrm{HL}$ was underneath them. Also individuals were divided in 2 groups categorized by the measured angle: individuals presenting angles higher than $+4^{\circ}$ and lower than $-4^{\circ}$ $\left(x-\leq-4^{\circ}\right.$ or $\left.x-\geq+4^{\circ}\right)$ were considered non-acceptable and angles varying between $-4^{\circ}$ and $+4^{\circ}\left(-4^{\circ}<x<+4^{\circ}\right)$ were considered acceptable.

\section{Statistical Analysis}

Normality of the data distribution was assessed with the Shapiro-Wilk test. Kruskal-Wallis and Dunn Multiple Comparison nonparametric tests were used to compare NHP determined by the three professionals. Same non-paremetric test was used to compare the three skeletal groups for each method. Mann-Whitney was used for gender comparison. Friedman test to compare three compare the 3 methods to estimate head position with no
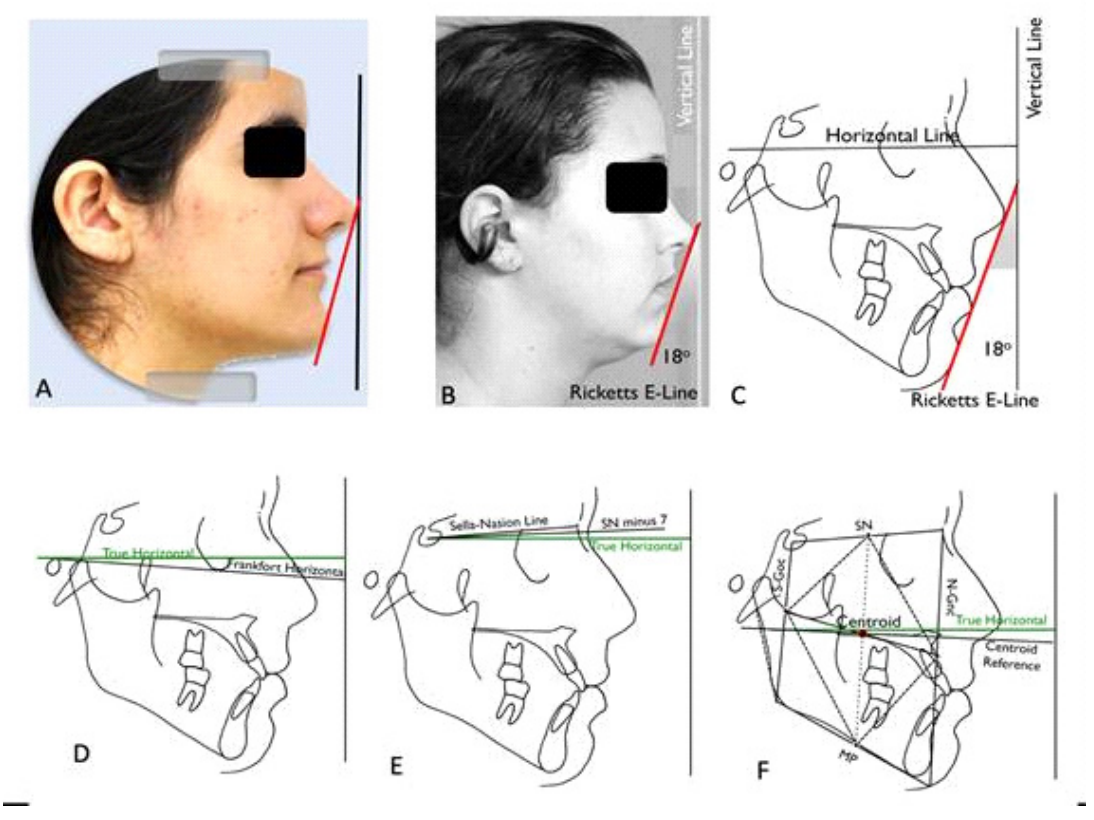

Figure 2. Photograph taken in NHP with the angle formed by the true vertical line and Ricketts E-line transferred to the cephalogram in order to reorientate the head position according to the photograph. 
skeletal discrepancy or gender distinction. Spearman's rank coefficient test were applied to compare the natural head position. A NcMemar test was used to compare two of the three methods separately. Data analysis was performed with SAS statistical software (SAS Institute Inc., Cary, NC, USA, Release 9.1, 2003) at significance level $p<0.05$ ).

\section{Error of method}

To test the method error, 43 cephalometric tracings, representing $20 \%$ of the overall sample, were randomly selected and re-traced, as well as all the landmarks and measures. The Wilcoxon Matched Pairs test were applied and did not show a p value $<0.05$ for all the three methods (SN7 ${ }^{\circ} \mathrm{p}=0.72$; Frankfort horizontal, $\mathrm{p}=0.085$; Centroid method, $p=0.32$ ).

\section{RESULTS}

The results showed that there was a significant difference between NHP experienced orthodontists $x$ orthodontic students $(p=0.0058)$ and surgeon $x$ orthodontic students groups $(p=0.0073)$. No difference was found between experienced orthodontist and orthognatic surgeon ( $p>0.9999)$ and the difference between values found were less than $1^{\circ}$ (figure 3 ).

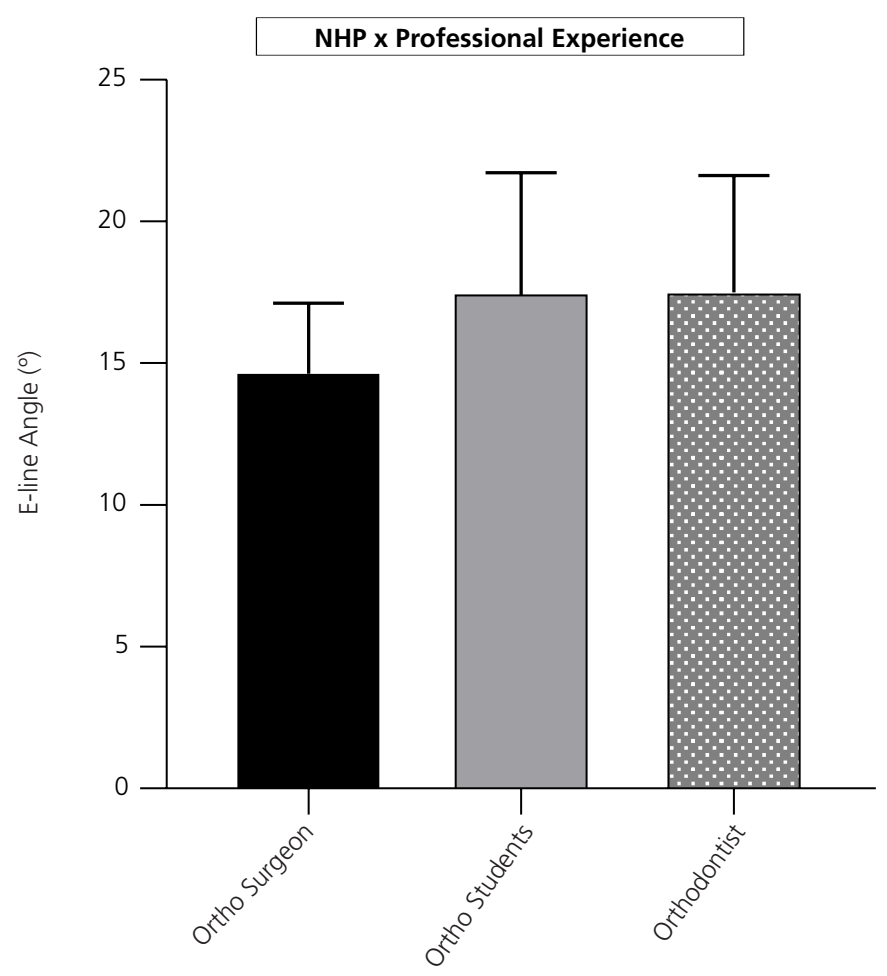

Figure 3. Graphical representation of the results comparing natural head position (NHP) obtained from 3 groups of clinicians with different experiences.

Table 1 shows median, minimum and maximum values for all the three methods, distributed by skeletal classification groups and genders. There were no

Table 1. Median, minimum value, maximum value are shown for each method and is divided by skeletal classification groups and gender.

\begin{tabular}{|c|c|c|c|c|c|c|}
\hline \multirow{3}{*}{ Group } & \multicolumn{6}{|c|}{ Gender } \\
\hline & \multicolumn{3}{|c|}{ Female } & \multicolumn{3}{|c|}{ Male } \\
\hline & Median & Minimum Value & Maximum Value & Median & Minimum Value & Maximum Value \\
\hline Group 1 & $2,75 \mathrm{Aa}$ & $-4,00$ & 13,00 & $2,00 \mathrm{Aa}$ & $-4,00$ & 10,00 \\
\hline Group 2 & $2,00 \mathrm{Aa}$ & $-5,00$ & 10,00 & $1,25 \mathrm{Aa}$ & $-3,00$ & 8,00 \\
\hline Group 1 & $0,00 \mathrm{Aa}$ & $-5,00$ & 8,00 & $-2,00 \mathrm{Aa}$ & $-7,00$ & 6,00 \\
\hline Group 2 & $-0,50 \mathrm{Aa}$ & $-6,00$ & 6,00 & $-2,00 \mathrm{Aa}$ & $-5,00$ & 3,00 \\
\hline Group 3 & $-2,00 \mathrm{Aa}$ & $-11,00$ & 9,00 & $-3,00 \mathrm{Aa}$ & $-8,00$ & 4,00 \\
\hline \multicolumn{7}{|c|}{ Centroid Reference } \\
\hline
\end{tabular}

Note: Group 1 - normal skeletal and occlusion. Group 2 - sagital skeletal discrepancy (skeletal Class II and III). Group 3 - vertical skeletal discrepancy (skeletal open bite and deep bite). 
statistically differences related to skeletal classification and gender ( $p>0.05$ ). Table 2 shows the results general results, including all skeletal discrepancies and gender. Both tables show that the three methods differ from each other $(p<0.01)$ and that the median for the Centroid method is close to zero, which means that it is extremely compatible with the true horizontal line. SN7 ${ }^{\circ}$ and Frankfort horizontal showed a higher variability for median and standard deviation.

Since $\mathrm{HL}$ obtained from NHP found by experienced professionals was used as reference, angles found larger or lower than $4^{\circ}$ were considered non-acceptable (high variability). A higher number and percentage of individuals

Table 2. Descriptive statistics of the overall sample.

\begin{tabular}{lccc}
\hline & $\begin{array}{c}\text { Centroid } \\
\left({ }^{\circ}\right)\end{array}$ & $\begin{array}{c}\text { Frankfort } \\
\left({ }^{\circ}\right)\end{array}$ & $\begin{array}{c}\text { SN7 }^{\circ} \\
\left({ }^{\circ}\right)\end{array}$ \\
\hline median & 0,00 & $-1,50$ & 2,00 \\
Standard deviation & 2,27 & 3,60 & 3,57 \\
$*$ & $\mathrm{~B}$ & $\mathrm{C}$ & $\mathrm{A}$ \\
\hline
\end{tabular}

within the acceptable variation range $\left(-4^{\circ}<x<4^{\circ}\right)$ was found in the Centroid method, i.e., 187 individuals (88.2\%) compared to $130(61.3 \%)$ for Frankfurt horizontal plane and $136(64.2 \%)$ for SN7. The number and percentage of individuals classified as non-acceptable ( $x \leq-4^{\circ}$ or $x \geq 4^{\circ}$ ) were 25 (11.8\%) for Centroid, 82 (38.7\%) for FRANK and 76 (35.8\%) for SN7 methods.

When the methods were compared separately in pairs, SN7 ${ }^{\circ}$ and Frankfort horizontal were found not statistically different $(p=0.3203)$, but both methods were significantly different from the Centroid method $(p<0.001)$ (table 3).
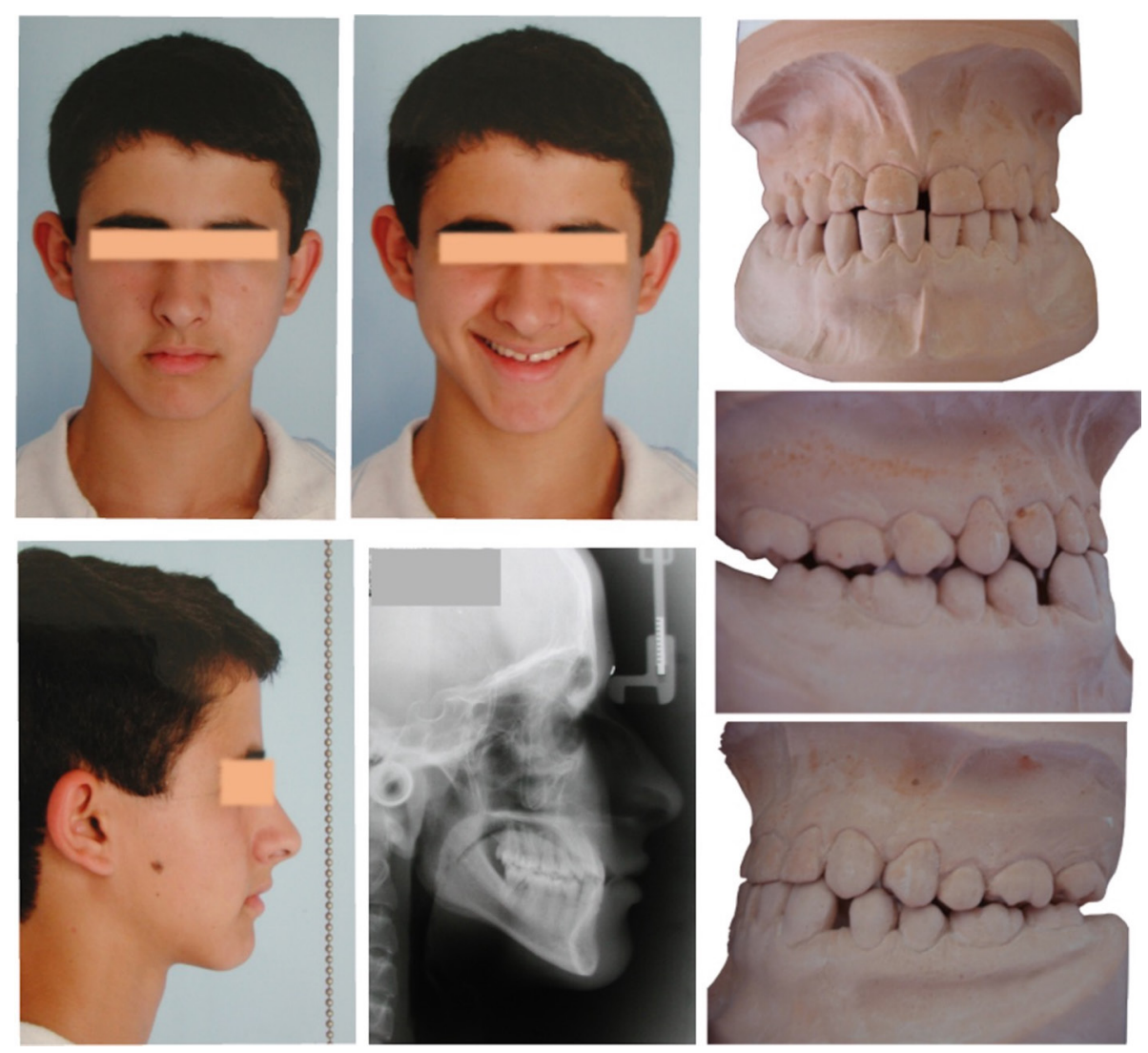

Figure 4. Facial and dental images and lateral x-ray of a 14 year-old patient presenting a skeletal Class III and Class III Angle malocclusion with uprighted lower incisors and proclined upper incisors. 
The Centroid method can be applied as the method of choice in cases when the clinician does not have the profile photograph of the patient or may be insecure on using the NHP taken by a non-experienced professional. A clinical example is shown in figures 4 and 5 , of facial and dental records of a 14 year-old patient. Study model shows a Class III Angle malocclusion with proclined upper incisors and lingual inclination of lower incisors, confirmed by the lateral xray. Such characteristics are usually found as dentoalveolar compensation on Class III skeletal patients. On the contrary, facial images, especially the profile picture allegedly taken in natural head position shows a convex profile with retrognatic mandible, which is contradictory with the clinical and xray findings (figure 4). When Wits measurement was performed based on NHP obtained on the photograph, a positive 40 was found, indicating a Class I maxillomandibular relationship (Figure 5). After tracing the cephalogram, head position was estimated using the Centroid method, by correcting the Centroid Reference Line (Centroid point to Subnasal), Wits was once again measured, but this time, the obtained value was -30 , thus expressing a skeletal Class III relationship which seems to corroborate with clinical findings.
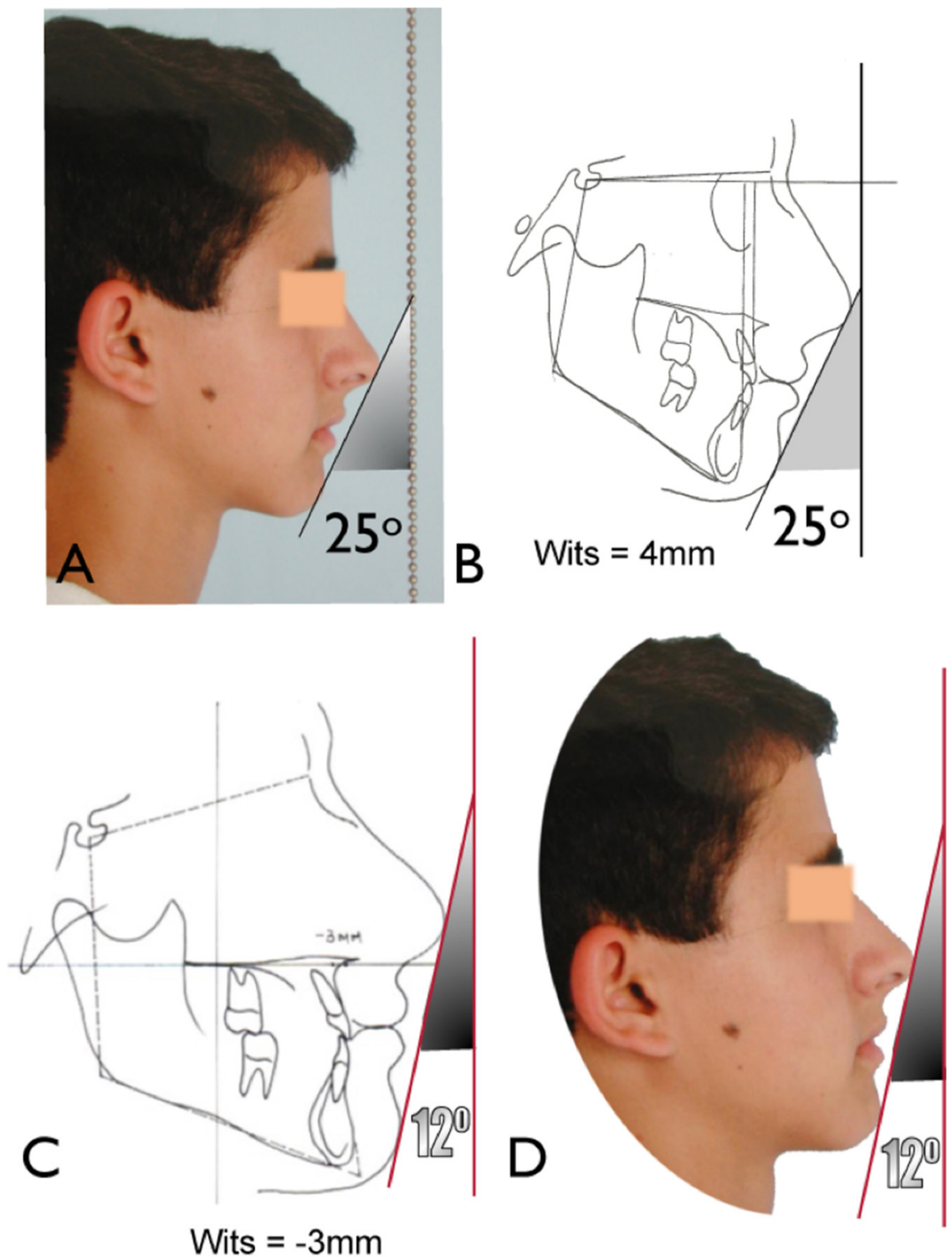

Figure 5. A,B- NHP obtained in the photograph transferred to the cephalogram showing a skeletal Class I. C,D - Centroid method showing a skeletal Class III discrepancy and after transference from the Centroid cephalogram to the profile picture. 


\section{DISCUSSION}

Cephalometrics aims to evaluate facial morphology by segmenting the craniofacial complex in order to study how skeletal compartments relate to each other $[19,20]$. Most common cephalometrics use intracranial landmarks relating to normal population (with no skeletal disorders) or extracranial references based on the natural head position. According to Lundström et al. [3], the intracranial method based on anatomical landmarks can often be unreliable since some landmarks can be hard to distinguish, thus, having a direct effect on the interpretation of the craniofacial morphology and skeletal discrepancy.

Our results showed that comparing Centroid method and Frankfort, there was a significant difference and the same result was found when comparing the Centroid method to SN7 ${ }^{\circ}$. No difference was found when comparing Frankfort horizontal to $S N 7^{\circ}$. Since median value of the measured angle obtained from Centroid method was equal 0 , this indicate that the proposed method to estimate head position has a close relation to the NHP established by the experienced professionals. Frankfort and SN7 ${ }^{\circ}$ presented greater variability. Probably due to a difficulty in locating precisely Porion point in the petrous portion of temporal bone [6] or a high variation to demarcate orbit point [21] in Frankfort horizontal. As to $\mathrm{SN}$, Moorrees [4] considered it as highly variable and mentioned that when the SN line is markedly inclined downward or upward, SNA (Sella-Nasion-Apoint) and SNPg (Sella-Nasion-Pogonion) angles may vary greatly. Another downside of using $\mathrm{SN}$ line is that nasion point is a established in a suture that changes during active growth in children, thus it may move forward and upward, or even downward during growth [22]. It might explain the high variation for $5 \mathrm{~N}^{\circ}$ and Frankfort horizontal references found in our study.

Studies have shown that extracranial reference using NHP minimizes intracranial variations, leading to a more accurate assessment of growth and dentocraniofacial anomalies and considered NHP method more reliable and highly reproducible $[1,2,4,6,8,11,23]$. Negreiros \& Smith [24] and Özbek \& Köklü [25] reported that angular and linear measurements show significant changes when NHP changed more than $5^{\circ}$. It is known that the change in head position equal or more than $5^{\circ}$ may conduct to an error in linear measurement as large as $10 \mathrm{~cm}$ [26], and thus incorrectly establishing facial morphology and as consequence, an incorrect diagnosis and treatment plan. Based on this, the present study used $4^{\circ}$ as a reference to consider variation of head position as acceptable $\left(-4^{\circ}<x<+4^{\circ}\right)$ or non-acceptable $\left(x \leq-4^{\circ}\right.$ ou $\left.x \geq+4^{\circ}\right)$. It was observed in our study that for all three groups, the number of individuals with acceptable values was greater than the non-acceptable values. Centroid method showed the highest number of individuals presenting angles varying between $-4^{\circ}$ and $4^{\circ}(88.2 \%)$ compared to the other methods. Frankfort method [27] showed $38.7 \%$ of indivuduals categorized as non-acceptables, thus greater variability of head position.

In addition, the minimum and maximum values related to the Centroid method were lower than $\mathrm{SN}$ minus 7 and Frankfort horizontal, $+13^{\circ}$ to $-5^{\circ}$ and $-11^{\circ}$ to $9^{\circ}$ respectively (Table 2 ). Confirming this data, Torres et al. [28] found minimum and maximum values of the angle formed by the Frankfurt Horizontal to vary between $-11.5^{\circ}$ and $+8^{\circ}$ in all 60 cases studied. The Centroid method showed the lowest variation of minimum and maximum values compared to other methods $\left(-6^{\circ}\right.$ to $\left.4^{\circ}\right)$. Therefore, the use of Centroid Reference Line showed less variation between the minimum and maximum values, and seems to be the most reliable method to estimate head position.

If the clinician does not have patient's lateral photograph or may be insecure on using the NHP taken by a non-experienced professional, Centroid method can be applied. A number of factors affects head posture, including craniofacial morphology [29], respiratory resistance, rapid maxillary expansion [30]. As explained previously at the results section, if photograph is not taken in a correct natural head position which at the majority of times, head needs to be adjusted by the clinician, it may mislead to interpretation of patient's facial profile, therefore the diagnosis of the skeletal problems. The method using the E-line angle to transfer head position from cephalogram to photograph and from photograph to cephalogram has been recommended by Park et al suggested the use of E-line angle found in profile photograph to be transfer to CBCT 3D image aiming to adjust head position and therefore, more accurately access anteroposterior skeletal relationships [31].

The relevance of this study lies on the fact that Centroid method represents a simple and objective approach for clinicians to evaluate the craniofacial complex. More research on the proposed method based on Cone Beam computed tomography should be encouraged to estimate 
head position on 3D model, increasing its applicability to benefit a more proper diagnosis of sagittal and vertical skeletal discrepancies and more accurate treatment plan.

\section{CONCLUSION}

- NHP seems to be dependent on professional experience. - Reorientation of cephalometric tracings using the Centroid method is a reliable, simple and objective method to estimate head position. - The Centroid method had the least variation compared to Frankfort horizontal and SN7 ${ }^{\circ}$ methods, thus it may assist clinicians to obtain a proper diagnosis and treatment plan.

\section{Collaborators}

H SUZUKI, idea and development of method, reviewing the manuscript; SS SUZUKI, application of statistical analysis, writing the manuscript; AS GARCEZ, development and design of the methodology, reviewing the manuscript; JM CARVALHAES, conducting the research and data collection; DN FUJII, sample gathering for the experiment; YBL ARSATI, advisor and reviewing and editing the manuscript.

\section{REFERENCES}

1. Broadbent H. A new x-ray technique and its application to orthodontia. Angle Orthod. 1981;51(2):93114. http://dx.doi. org/10.1043/00033219(1931)001\%3C0045:ANXTAI\%3E2. $0 . \mathrm{CO} ; 2$

2. Cooke MS, Wei SH. The reproducibility of natural head posture: a methodological study. Am J Orthod Dentofacial Orthop. 1988;93(4):280-288. http://dx.doi.org/10.1016/08895406(88)90157-6

3. Lundström A, Lundström F, Lebret LML, Moorrees CFA. Natural head position and natural head orientation: Basic considerations in cephalometric analysis and research. Eur J Orthod. 1995;17(2):111-20. http://dx.doi.org/10.1093/ejo/17. 2.111

4. Viazis AD. Comprehensive assessment of anteroposterior jaw relationship. J Clin Orthod. 1992;26(10):673-80.

5. Meiyappan, S. Tamizharasi, K.P. Senthilkumar KJ. Natural head position: An overview. Dent Sci. 2015;7(6):424-7. http:// dx.doi.org/10.4103/0975-7406.163488

6. Moorrees CFA. Natural head position-a revival. Am J Orthod Dentofacial Orthop. 1994 May;105(5):512-3. http://dx.doi. org/10.1016/S0889-5406(94)70014-1

7. Siersbæk-Nielsen S, Solow B. Intra- and interexaminer variability in head posture recorded by dental auxiliaries. Am J Orthod. 1982;82(1):50-7. http://dx.doi.org/10.1016/0002-9 416(82)90546-2
8. Solow B, Tallgren A. Natural head position in standing subjects. Acta Odontol Scand. 1971;29(5):591-607. http:// dx.doi.org/10.3109/00016357109026337

9. Dvortsin DP, Ye Q, Pruim GJ, Dijkstra PU, Ren Y. Reliability of the integrated radiograph-photograph method to obtain natural head position in cephalometric diagnosis. Angle Orthod. 2011;81(5):889-94. http://dx.doi.org/10.2319/010411-2.1

10. Cassi D, De Biase C, Tonni I, Gandolfini M, Di Blasio A, Piancino MG. Natural position of the head: Review of twodimensional and three-dimensional methods of recording. $\mathrm{Br} J$ Oral Maxillofac Surg. 2016;54(3):233-40. http://dx.doi. org/10.1016/j.bjoms.2016.01.025

11. Cooke MS, Hons B, Orth D, Eng DRCS, Edin FDSRCS. Five-year reproducibility of natural head posture: A longitudinal study. 1990;489-94. http://dx.doi.org/10.2319/010411-2.1

12. Bister D, Edler RJ, Tom BDM, Prevost AT. Natural head postureconsiderations of reproducibility. 2002;24:457-70. http://dx. doi.org/10.1093/ejo/24.5.457

13. Madsen DP, Sampson WJ, Townsend GC. Craniofacial reference plane variation and natural head position. Eur J Orthod. 2008;30(5):532-40. http://dx.doi.org/10.1093/ejo/cjn031

14. Johnson JS. A new approach to cephalometric analysis of the dental base relationship. Angle Orthod. 1978;48(1):23-32. http://dx.doi.org/10.1043/0003-3219(1978)048<0023:ANAT CA $>2.0 . \mathrm{CO} ; 2$

15. Johnson JS, Hubbold RJ. An Introduction to Centroid Cephalometrics. Br J Orthod. 2014;9(1):32-6. http://dx.doi. org/10.1179/bjo.9.1.32

16. Trenouth MJ, M.J. T, MJ T. Centroid analysis of twin-block appliance treatment for Class II Division 1 malocclusion. World J Orthod. 2006;7(2):159-64.

17. Fishman LS. Individualized evaluation of facial form. Am J Orthod Dentofacial Orthop. 1997;111(5):510-7. http://dx.doi. org/10.1016/s0889-5406(97)70288-9

18. Sarhan OA, Al- Balkhi KM. Geometrical interpretation for abnormal facial behaviour with possible correction of angle S- N- A and S N- B. J Oral Rehabil. 1993;20(2):233-9. http:// dx.doi.org/10.1111/j.1365-2842.1993.tb01605.x

19. Holdaway RA. A soft-tissue cephalometric analysis and its use in orthodontic treatment planning. Part II. Am J Orthod. 1984;85(4):279-93. http://dx.doi.org/10.1016/00029416(83)90144-6

20. Downs WB. Variations in facial relationships: Their significance in treatment and prognosis. Am J Orthod. 1948;34(10):812-40. http://dx.doi.org/10.1016/0002-9416(48)90015-3

21. Midtgard J, Bjork G, Linder Aronson S. Reproducibility of cephalometric landmarks and errors of measurements of cephalometric cranial distances. Angle Orthod. 1974;44(1):56-61. http://dx.doi.org/10.1043/0003-3219(1974) 044<0056:ROCLAE $>2.0 . C O ; 2$

22. Akgül AA, Toygar TU. Natural craniofacial changes in the third decade of life: A longitudinal study. Am J Orthod Dentofac Orthop. 2002;122(5):512-22. http://dx.doi.org/10.1067/mod. 2002.128861 
23. Lundström F, Lundström A. Natural head position as a basis for cephalometric analysis. Am J Orthod Dentofac Orthop. 1992;101(3):244-7. http://dx.doi.org/10.1016/0889-5406 (92)70093-P

24. Negreiros PE, Siqueira VCV de. O efeito da alteração da posição natural da cabeça (PNC) sobre as medidas cefalométricas. Rev Dent Press Ortod e Ortop Facial. 2011;9(3):59-76. https://doi. org/10.1590/S1415-54192004000300007.

25. Ozbek MM, Koklu A. Extracranial versus intracranial references in individual cephalometric analysis. $\mathrm{Br} \mathrm{J}$ Orthod. 1994;21(3):259-63. http://dx. doi.org/10.1179/bjo.21.3.259

26. Spolyar JL. Head positioning error in cephalometric radiography-an implant study. Angle Orthod. 1987;57(1):77-88. http:// dx.doi.org/10.1043/0003-3219(1987)057<0077:HPEICR $>2.0 . \mathrm{CO} ; 2$

27. Verma SK, Maheshwari S, Gautam SN, Prabhat KC, Kumar S. Natural head position: Key position for radiographic and photographic analysis and research of craniofacial complex. J Oral Biol Craniofacial Res. 2012;2(1):46-9. http://dx.doi. org/10.1016/S2212-4268(12)60011-6

28. Tôrres SC, Costa C, Faltin Jr. K. Estudo da posição natural da cabeça em relação ao plano horizontal de Frankfurt na avaliação mandibular de indivíduos com padrão facial de Classe I e Classe II. Rev Dent Press Ortod e Ortop Facial. 2006;11(1):84-98.

29. Mcguinness NJ, Mcdonald JP. Changes in natural head position observed immediately and one year after rapid maxillary expansion. 2006;28:126-34. http://dx.doi.org/10.1093/ ejo/cji0 64

30. Tecco S, Festa F, Tete S, Longhi V, D'Attilio M. Changes in head posture after rapid maxillary expansion in mouth-breathing girls: A controlled study. Angle Orthod. 2005;75(2):171-6. http://dx.doi.org/10.1043/0003-3219(2005)075<0167:CIHP $A R>2.0 . C O ; 2$

31. Park Y, Cho Y, Mah J, Ahn J. Assessment of anteriorposterior jaw relationships in Korean adults using the nasion true vertical plane in cone-beam computed tomography images. Korean J Orthod. 2016. http://dx.doi.org/10.4041/ kjod.2016.46.3.163

Received on: 28/4/2019 Final version resubmitted on: 11/6/2019 Approved on: 18/6/2019 